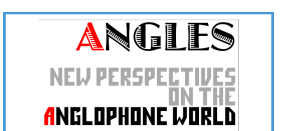

ANELOPHONE WORLD

\section{Angles}

New Perspectives on the Anglophone World

9 | 2019

Reinventing the Sea

\title{
Sailing the Indian Ocean in Ancient Times
}

Jean-Marie Kowalski

\section{Q OpenEdition}

\section{Journals}

Electronic version

URL: https://journals.openedition.org/angles/800

DOI: 10.4000/angles.800

ISSN: 2274-2042

\section{Publisher}

Société des Anglicistes de l'Enseignement Supérieur

\section{Electronic reference}

Jean-Marie Kowalski, "Sailing the Indian Ocean in Ancient Times", Angles [Online], 9 | 2019, Online since 01 November 2019, connection on 06 June 2022. URL: http://journals.openedition.org/angles/ 800 ; DOI: https://doi.org/10.4000/angles.800

This text was automatically generated on 6 June 2022.

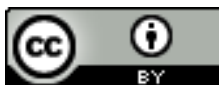

Angles est mise à disposition selon les termes de la Licence Creative Commons Attribution 4.0 International. 


\title{
Sailing the Indian Ocean in Ancient Times
}

\author{
Jean-Marie Kowalski
}

1 The oceans are no longer wide water deserts, but rather connections between continents, peoples and their economies. This is the picture of what is usually called globalization. Thanks to maritime routes, the sea is not a territory, but a particular space that looks like a huge network with human and commercial flows on seaways connected by harbors, narrow straits or canals, but also intersections. These routes are also highly dependent on the environment and changing weather conditions, but also changing weather systems from one place to another. A maritime route can be opened in some seasons, and closed in others.

2 We will not address $21^{\text {st }}$ century maritime routes, but go far back in time, at an early globalization movement in Ancient times initiated by Greek merchants and sailors who gradually came to sail across the oceans and discovered new territories, notably the Indian Ocean - our main focus in this paper (Fig. 1). Although one can assume that there was a "World System" in the Bronze Age, progressive changes in the Ancient world came to a turning point by the $1^{\text {st }}$ century AD (Beaujard, 2009), when connexions between different networks, but also regular and significant trade, built an AfroEurasian world system with three major core regions evolving synchronously from the Mediterranean to the China Sea. On the Western side, the accumulated sailing experience of the Indian Ocean both shaped literary representations and set the basic features of medieval maps. Our purpose is to focus on the encounter between the Indian Ocean and these Greek and Roman spatial representations, shaped by navigation in a specific environment. 
Figure 1. A world shaped by maritime routes

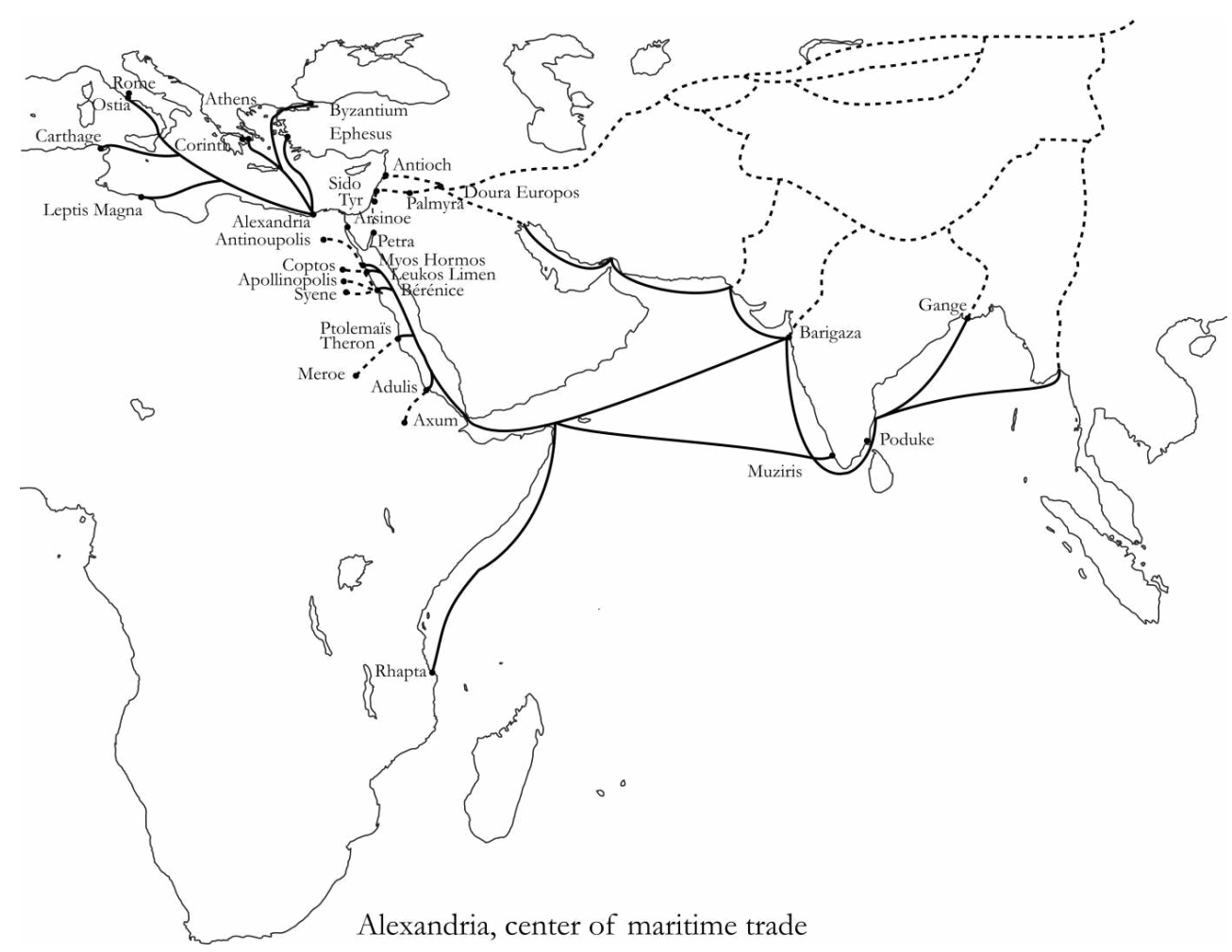

3 After discussing the different historical sources available to us (such as Arrian, Strabo, Agatharchide, and Pliny the Elder), we will see how these sources described the Indian Ocean and its importance in trade routes. Although these sources did not seem to draw the map of India, almost as if it did not exist, navigators and merchants knew about this area. Following Ptolemy and accounts by merchants and others, we will discuss the Ancients' "experience" of the Indian Ocean, and the manner in which it was represented in the form of maps and likened to other areas of the world they were more familiar with.

\section{Historical Background and Sources}

4 In what follows, our point of view will be biased, as we will only address Greek and Roman representations of the Indian Ocean without discussing Asian and Indian sources detailing navigation across this area (Marcotte 2016), even if other peoples also navigated in those waters before, during and after Europe's classical antiquity. For instance, the lack of written evidence of Arabian navigations before the Greek and Roman era does not mean that people from the Middle East did not sail at all: during the Achaemenid and Seleucid periods, trade routes between India and the West were first maritime routes to the Arab-Persian Gulf; afterwards, cargo was transferred through the Arabian Peninsula by caravans handled by the Gerrhaeans (Salles 1993).

From a Western perspective, the career of Alexander the Great can be considered as a major turning point. After a global recession during the first half of the $4^{\text {th }}$ century BC, the South-Eastern part of Europe boasted a new period of development under the reigns of Philip II of Macedonia and Alexander the Great (Beaujard 2012). Under the reign of Alexander, Nearchus, the admiral of his fleet, visited the Iranian coast, but he 
did not explore the Arabian coast he had planned to visit. In $326 \mathrm{BC}$, Alexander sent his admiral with a fleet of more than 400 ships from the mouths of the Indus River to Susia, in the Persian Gulf (Marcotte 2013). It took him one year to get there. Unfortunately, Nearchus' works are lost, but large passages remain thanks to Flavius Arrianus (Hammond 2007). Arrian's description of the Indian coastline is a major contribution to the Ancients' representation of India using parallel lines. Another sailor from Alexander's expedition, Onesicrites, gave a similar picture of India, including a huge Sri Lanka.

Alexander's expedition to India was certainly a major military event, but it also had consequences on maritime trade in the Hellenistic era. Alexander's decision to make Alexandria the capital of his empire in 331 had a tremendous impact on the connection between the Mediterranean and the Indian Ocean. His decision made it clear that maritime routes were the routes of this Ancient globalization movement that subsequently shaped European representations of the world (Méla \& Möri 2014; Khalil 2005). His empire was designed as a network of maritime routes, centering on Alexandria in Egypt (more than 70 additional cities called Alexandria were founded by Alexander during his reign).

After his death, Alexander's successors divided his empire. Two should be specifically mentioned here: the Ptolemies and the Seleucids (Anson 2014). The Ptolemies quickly gained a strong leadership over the Mediterranean coast, and the Seleucids had to leave their positions in this area but became stronger along the Persian Gulf (Fig. 2). The Seleucids' leadership was already challenged by Arab navigators at that time.

Figure 2. Kingdoms of Alexander's successors

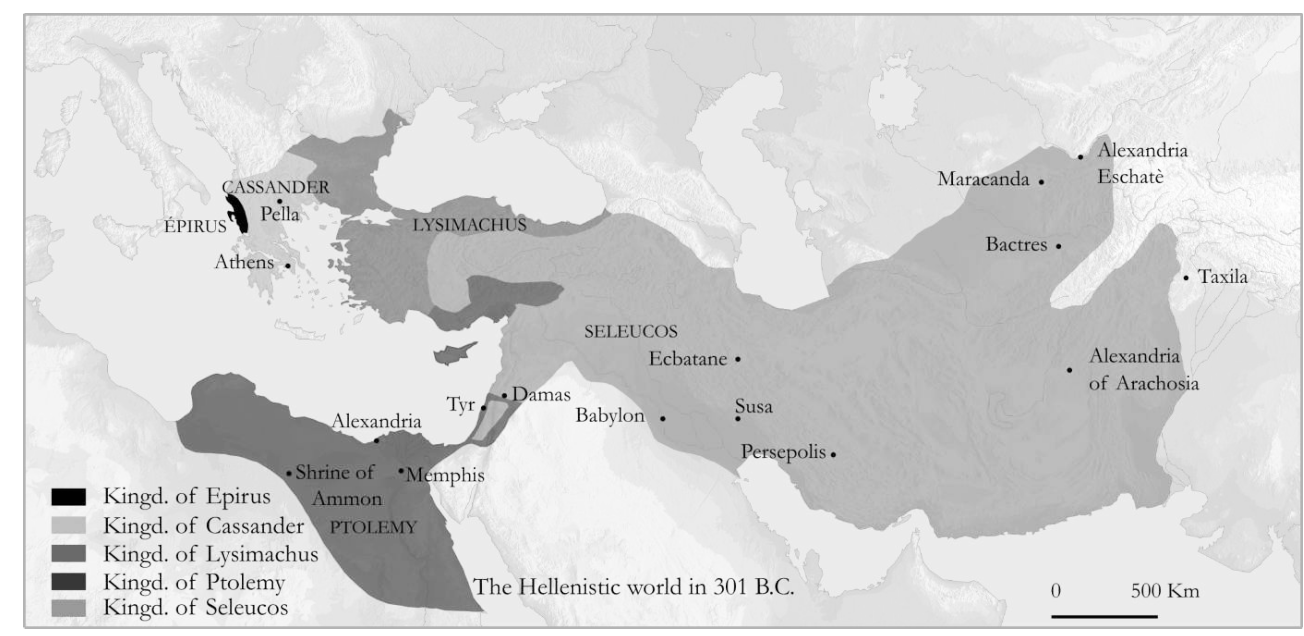

The Mediterranean, the Red Sea and the Indian Ocean gradually became interconnected. From the second half of the $3^{\text {rd }}$ century to the $2^{\text {nd }}$ century $\mathrm{BC}$, Egypt and Mesopotamia declined because of six Syrian wars and internal conflicts. Babylonia even suffered an epidemic and starvation in $274 \mathrm{BC}$. The interruption of the flow of caravans through the Arabian peninsula caused by Syrian wars may have forced the Ptolemies to sail through the Red Sea, but the Bal-al-Mandab strait was not regularly crossed by western sailors before the end of the $2^{\text {nd }}$ century $B C$ and it was not before $100 \mathrm{BC}$ that Egypt and the Red Sea were opened to Indian trade. 
In those times, the centre of gravity of the European world had shifted west and the Romans had enforced their naval leadership over the Western Mediterranean after the destruction of Carthage in 146 BC. According to Strabo:

Since the Romans have recently invaded Arabia Felix with an army [...] and since the merchants of Alexandria are already sailing with fleets by way of the Nile and of the Arabian Gulf as far as India these regions have become far better known to us of today than to our predecessors. At any rate, when Gallus was prefect of Egypt, [...] I learnt that as many as one hundred and twenty vessels were sailing from Myos Hormos to India, whereas formerly, under the Ptolemies, only a very few ventured to undertake the voyage and to carry on traffic in Indian merchandise. (Strabo 2.5.12)

He adds:

Now my first and important concern [...] is this to try to give, in the simplest possible way, the shape and size of that part of the earth which falls within our map. (Strabo 2.5.13)

10 Geopolitics and international relations also contributed to shape the representations of the world: by the end of the $2^{\text {nd }}$ century $\mathrm{BC}$, the Seleucid supremacy over Babylonia and the Gulf was challenged by the Parthians, who had difficult relations with the Romans up to the reign of Trajan ( $1^{\text {st }}$ and $2^{\text {nd }}$ centuries $A D$ ). In those conditions, the maritime trade route between the Western world and India naturally became more favorable even if one cannot affirm that trade patterns suddenly shifted from the ArabianPersian Gulf to the Red Sea (Salles 1993).

11 During the Hellenistic and Roman times, sources became more valuable, even if they remain quite fragmentary and do not provide us with information about the entire Indian Ocean (Arnaud 2005; Müller 1855, 1861). One source is Agatharchide's late $2^{\text {nd }}$ century BC description of the Red Sea, based on eyewitnesses and written documents from Alexandria in Egypt. Agatharchide's work is based on Ariston, an explorer who sailed along the western Arabian coast for one of the Ptolemies (probably Ptolemy II Philadelphus, who ruled Egypt during the first half of the $3^{\text {rd }}$ century $\mathrm{BC}$ ). Therefore, one can hardly know if the information given is based on the $3^{\text {rd }}$ century or $2^{\text {nd }}$ century $\mathrm{BC}$.

During the late $1^{\text {st }}$ century $\mathrm{BC}$ and at the very beginning of the $1^{\text {st }}$ century AD, Strabo wrote his Geography. Later, during the second half of the $1^{\text {st }}$ century, a Greek merchant from Egypt wrote Periplus of the Erythrean Sea (Periplus maris erythraei) for merchants and sailors who planned to sail along the Western coast of the Indian ocean (Casson 1989). It included detailed information about the sailing conditions, ports and products of the Red Sea coast, Somalia, but also western India, but did not seem to be very familiar with the Persian Gulf. It is highly probable that details were based on the author's personal experience of sailing along these coasts, while in other parts (East Africa, most of Arabia, and India south of modern-day Bombay), he relied on the statements of merchants with whom he was in contact. This document is the most important source on this particular issue, and the most global synthesis of the Indian Ocean which Greek and Roman merchants were actually familiar with. Many representations changed within the few decades since Strabo's Geography had first appeared: now the ecoumene reached Zanzibar in the South, but also the Gulf of Bengal and China in the East. Authors like Ptolemy knew of these evolutions of geographical knowledge, but Ptolemy later proposed a synthesis of both traditional representations and sailors' experiences. 

evidence of the existence of Greek or Roman maps of the Indian Ocean or any other sea. The most famous maps are Ptolemy's, even if they are copies from the Middle Ages. Ptolemy's information was based on longitude and latitude data about cities, harbors, mouths of rivers and other remarkable geographic entities. His description of the world with latitude and longitude coordinates provides the basic features required to draw maps, but the most ancient maps extant date back only to a $13^{\text {th }}$ century Byzantine manuscript (Biblioteca Apostolica Vaticana, Urb. Gr. 32). These maps became famous and many copies were made from the end of the $14^{\text {th }}$ century to the end of the $15^{\text {th }}$ century. Unfortunately, they do not help us understand the geographer's views.

A geographer's representation of geographic areas actually looks like a cloud of points rather than a continuous coastline, borders or rivers (Fig. 5). This draws a highly specific mental map of the world in which it looks as if India did not exist at all: the Indus mouth and Taprobane (modern-day Sri Lanka) "exist," but the main part of the Indian subcontinent does not, as navigators only experienced few places in this area (see Fig. 3 and 4 ). 
Figure 3. Taprobane in Ptolemy's Claudii Ptolemaei Alexandrini geographicae enarrationis

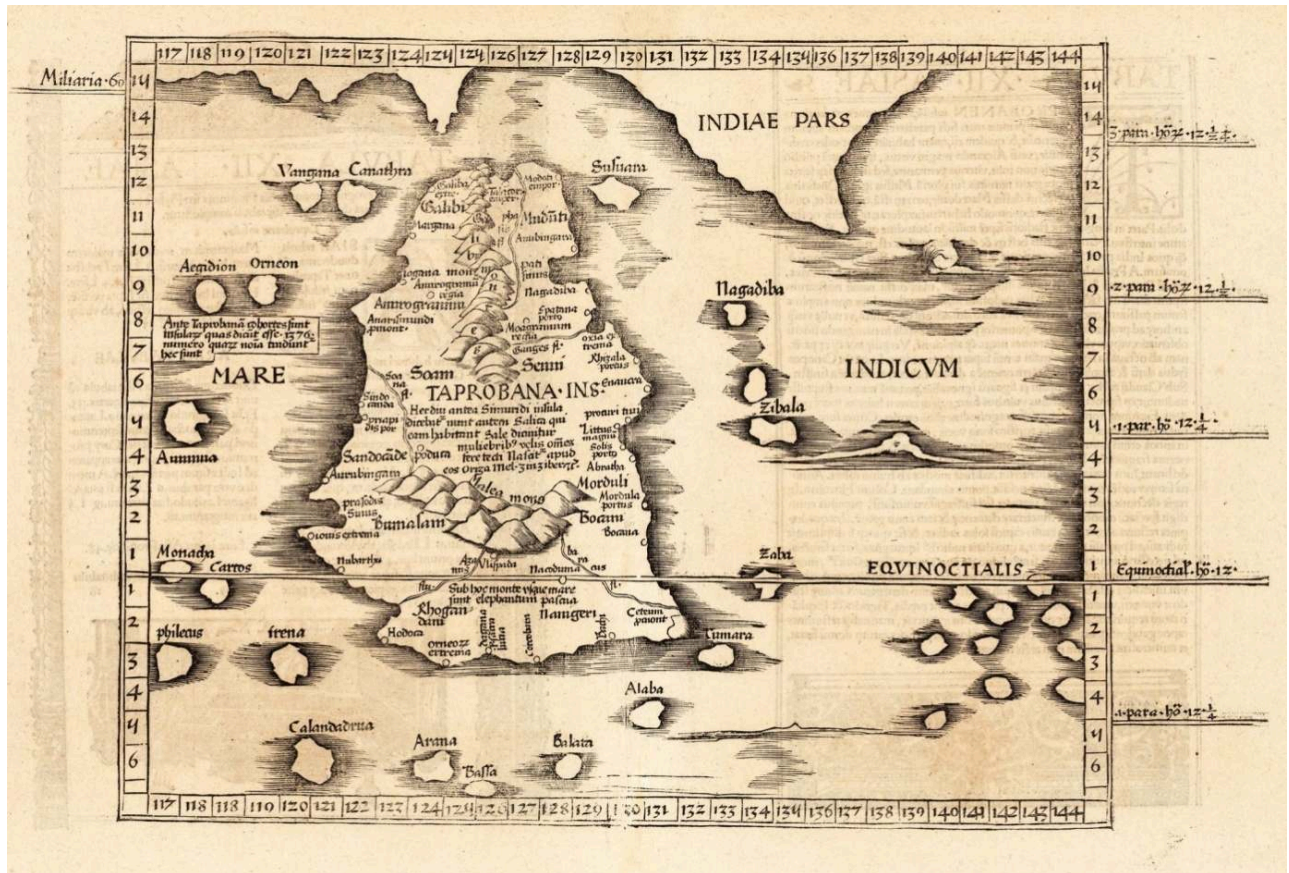

Libri octo, 1535.

This representation can be synthesized in the following way:

Figure 4. Elisée Reclus' view of Ptolemy's Geography

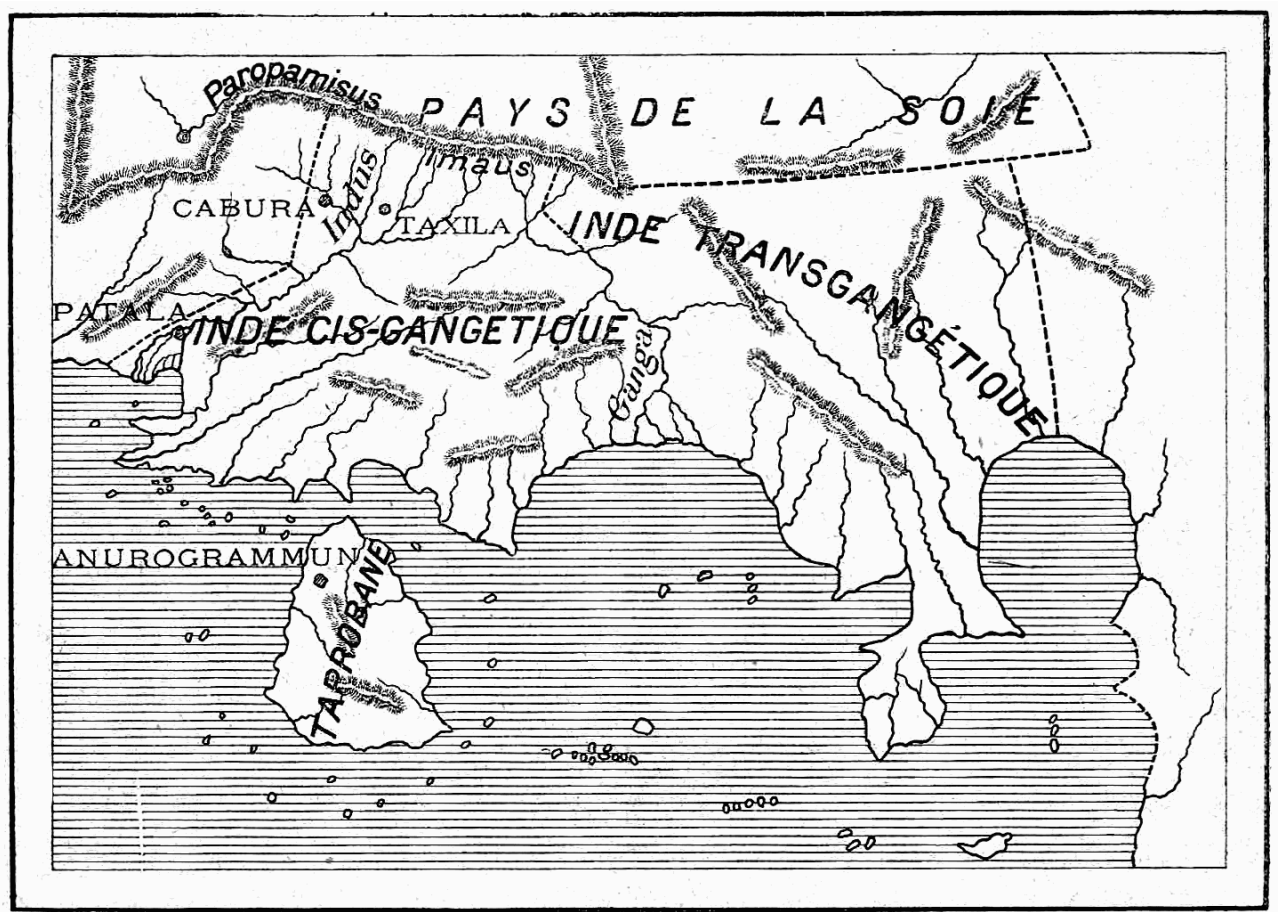

Elisée Reclus 1905: 111

18 These were not the first maps of the inhabited world, but they were the most famous. Geographers like Ptolemy proposed representations of the Eastern part of the world that relied both on a long-lasting scientific tradition and on the experience of 
navigators that improved the quality of representations. As a result, these highly experience-based "maps" were deeply biased, as they gave information about "salient" places in merchants' and navigators' mental maps rather than about physical geography, hydrography and the actual dimensions of the inhabited world.

Salience is both a qualitative and a quantitative concept: some geographic entities are structural elements of space that shape the sailors' and geographers' representations and organize space because they are useful landmarks and nodes on the network of maritime routes. Some of these entities, such as capes or promontories, are visually salient, but others have a more cognitive relevance, characterized by their capabilities: to protect ships, to offer safe mooring places, to land on shore, to provide ships with fresh water or to make seafaring possible.

Ancient texts tell us more than about geography: they provide us with clues to understand people's relationship with their environment. The definition of geographic entities itself depends on this relationship rather than on formal features. The ecological approach of visual perceptions designed in the field of psychology (Gibson 1979) provides us with relevant means for analyzing these representations. Gibson used a neologism, "affordance," to describe whatever capabilities the surrounding environment provides to human beings. The theory of affordances is not a modern essentialism as these "affordances" are not attributes of objects but point to the relationship between these objects and people. As a result, different geographic entities can be endowed with the same affordance: a wharf, a cape or a bay can equally provide sailors with the affordance to protect their ships. At the same time, one single geographic entity may have different affordances, according to the different activities of people: a bay with shallow waters with rocks may have the affordance to protect small ships, but also the affordance to be a danger for bigger ones, or the affordance to provide fishermen with a good fishing spot.

21 The psychological concept of affordance sheds new light on salience that seems ambiguous, as salience combines quantitative and qualitative features, measurable and cognitive ones, but also geographical and cultural items. As a result Taprobane seems to be much bigger than the Indian subcontinent which is reduced to the mouths of the Indus, while Tabropane seems to be surrounded by many smaller islands, as shown in the following maps.

In these documents, it looks as if the Indian subcontinent did not exist. India is nothing but an illusion for the Western world in Ancient Greek and Roman times. The Indus's mouth actually "exists" as Ptolemy locates eight mouths of the Indus River. The Ganges's mouth also "exists," but the continental part of India South of these places does not. One can easily distinguish on the left-hand side the northernmost part of the Arabian Sea which is said to be a kolpos ("a gulf"), the Gulf of Bengal, which Ptolemy calls "Gulf of Ganges," and the "Great Sea," situated south of China, on the right-hand side. India does not exist per se, but Taprobane does, with many surrounding islands; Malaysia and Indonesia are merged into a single peninsula in the Far East. Even if India does not seem to exist in these maps, this does not mean ancient sailors and geographers ignored this part of the world. More probably, they did not mention places that were of no use to them on their maritime routes. Even if one cannot draw a map of India from the indications given in Ancient texts, India obviously "exists" in Greek geographic literature. The following picture shows the 
different locations Ptolemy mentions in his Geography, with their longitude and their latitude (Fig. 5). Longitude is calculated from the first meridian, which is situated in the Atlantic Ocean, in the vicinity of the Canary Islands. Latitude is calculated from the equator.

Figure 5. Data of the Indian Ocean represented by Ptolemy

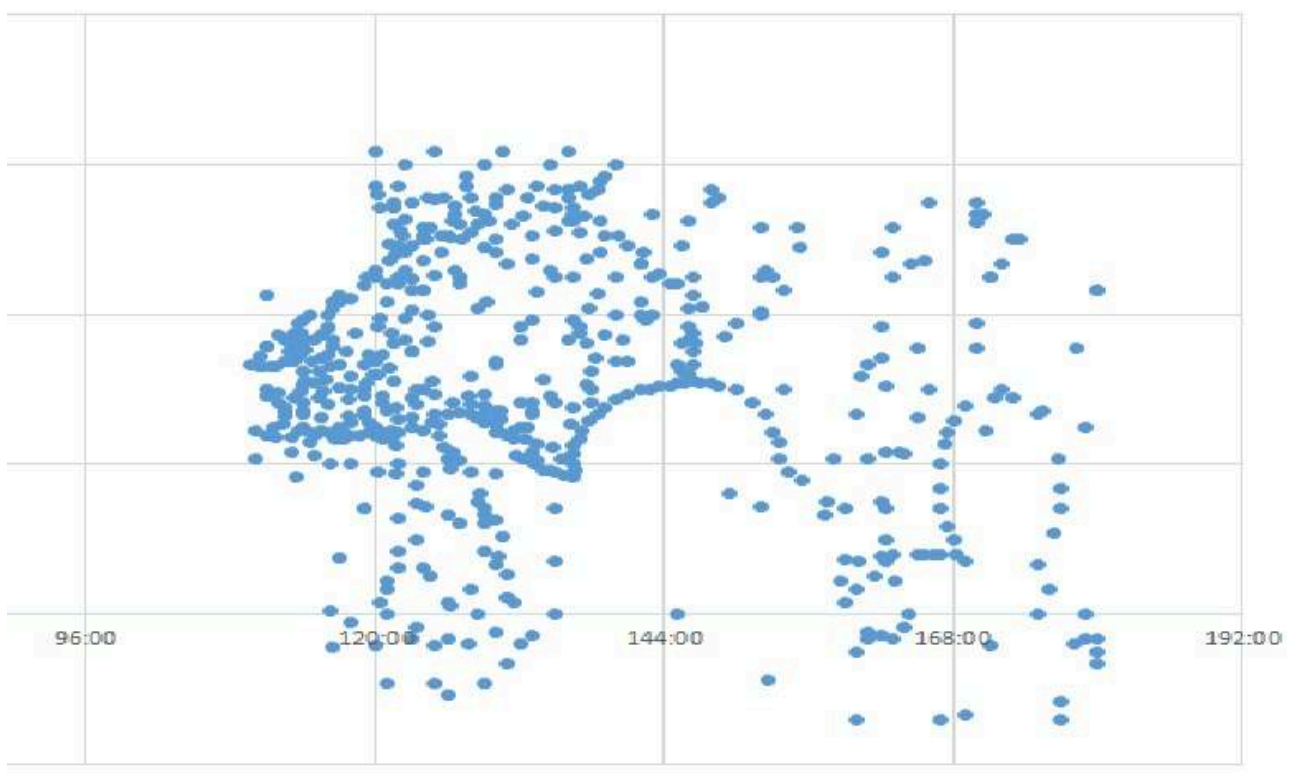

There is a sharp contrast between the $13^{\text {th }}$ century cartographic representations and Ptolemy's textual evidence. The geographer mentions 516 different locations in India, and 66 in Taprobane. 89 places he mentions in India are situated on the sea coast; 46 are situated on the Western Coast, north of Commaria promontorium, the southernmost cape of India. The density of points is much more important in this area.

This representation should be compared with the map by Elisée Reclus (Fig. 4), which raises several issues. First, the granularity of information is far less precise for Sri Lanka and the Far East than for the Northernmost part of India. Second, this granularity of information and the global frame of Ptolemy's description question the nature of boundaries in the Ancient world. India seems to be a consistent entity from the Indus to the Ganges River while Taprobane is described in a separate chapter.

The previous representations of the Indian Ocean can be connected with the Ptolemaic representations of Eastern Africa. In Fig. 6, it looks as if there were two major capes on the Western part of the Indian Ocean. The first is Syagros akra (this cape is called Ras Fartak in Yemen, see Ptolemy 6.7). The latitude of this cape is situated slightly south of the Indus's mouths and the Barygaza kolpos (modern Bharuch, and Gulf of Cambay). 


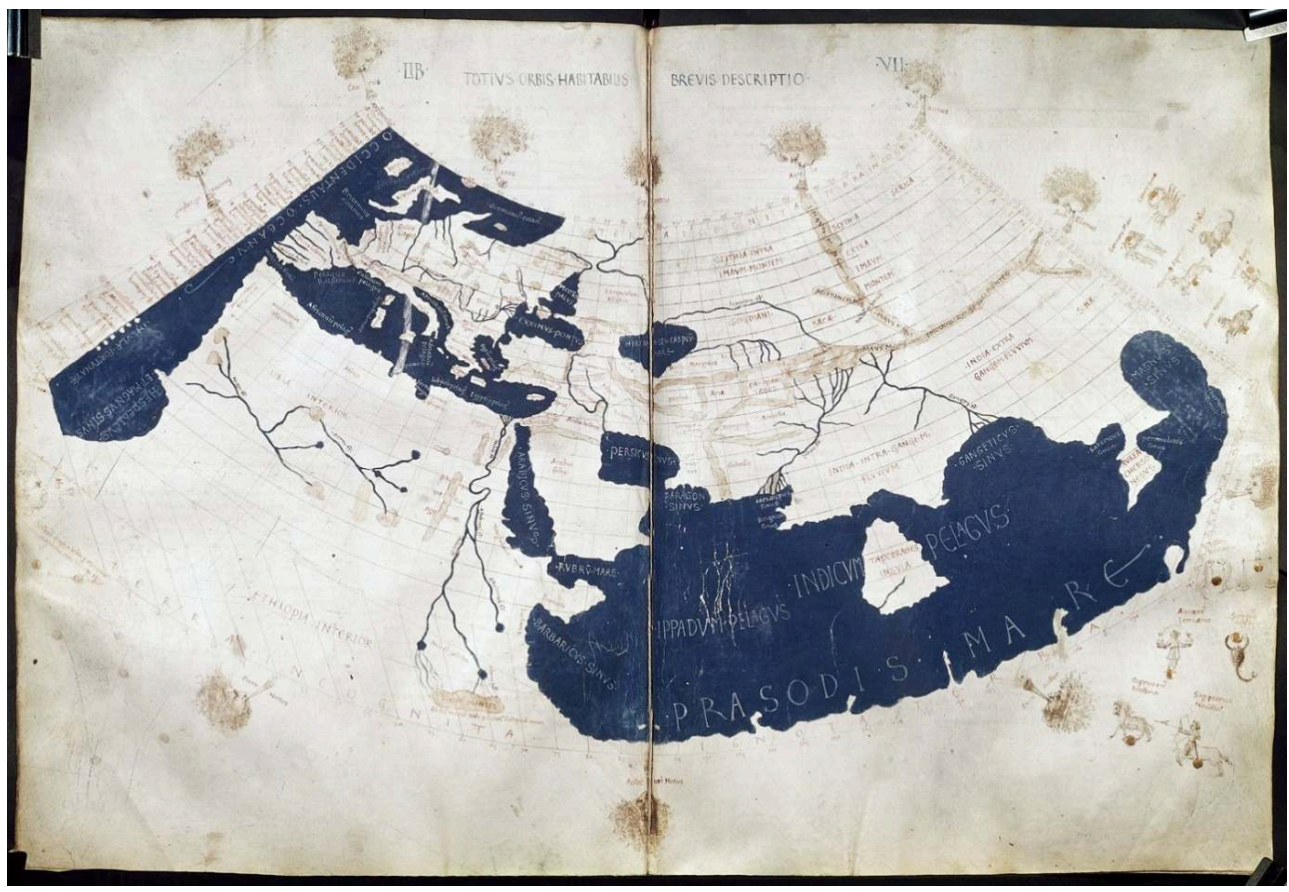

A mid-15th century Florentine map of the world based on Jacobus Angelus's 1406 Latin translation of Maximus Planudes's late $13^{\text {th }}$ century rediscovered Greek manuscripts of Ptolemy's Geography.

Source: Wikipedia

The second cape is the Aromata cape, the "spice cape" (long $83^{\circ}$, lat $06^{\circ}$ ), situated on the same latitude as the mouth of the Soana River in Taprobane and close to Rhizala harbor on the western coast of this island.

\section{Experience-based Representations of the Indian Ocean}

In the $3^{\text {rd }}$ century $\mathrm{BC}$, Eratosthenes described a different world that extended less to the east, but shared a common vision of this area. It was as if India did not really exist, but the mouths of the Indus River were already situated on the same latitude as Ras Khalfat, which was not mentioned at all. Taprobane was further south. It was already a huge island, which nevertheless remained smaller than the British Isles (Fig. 7). 
Figure 7. Eratosthenes' world

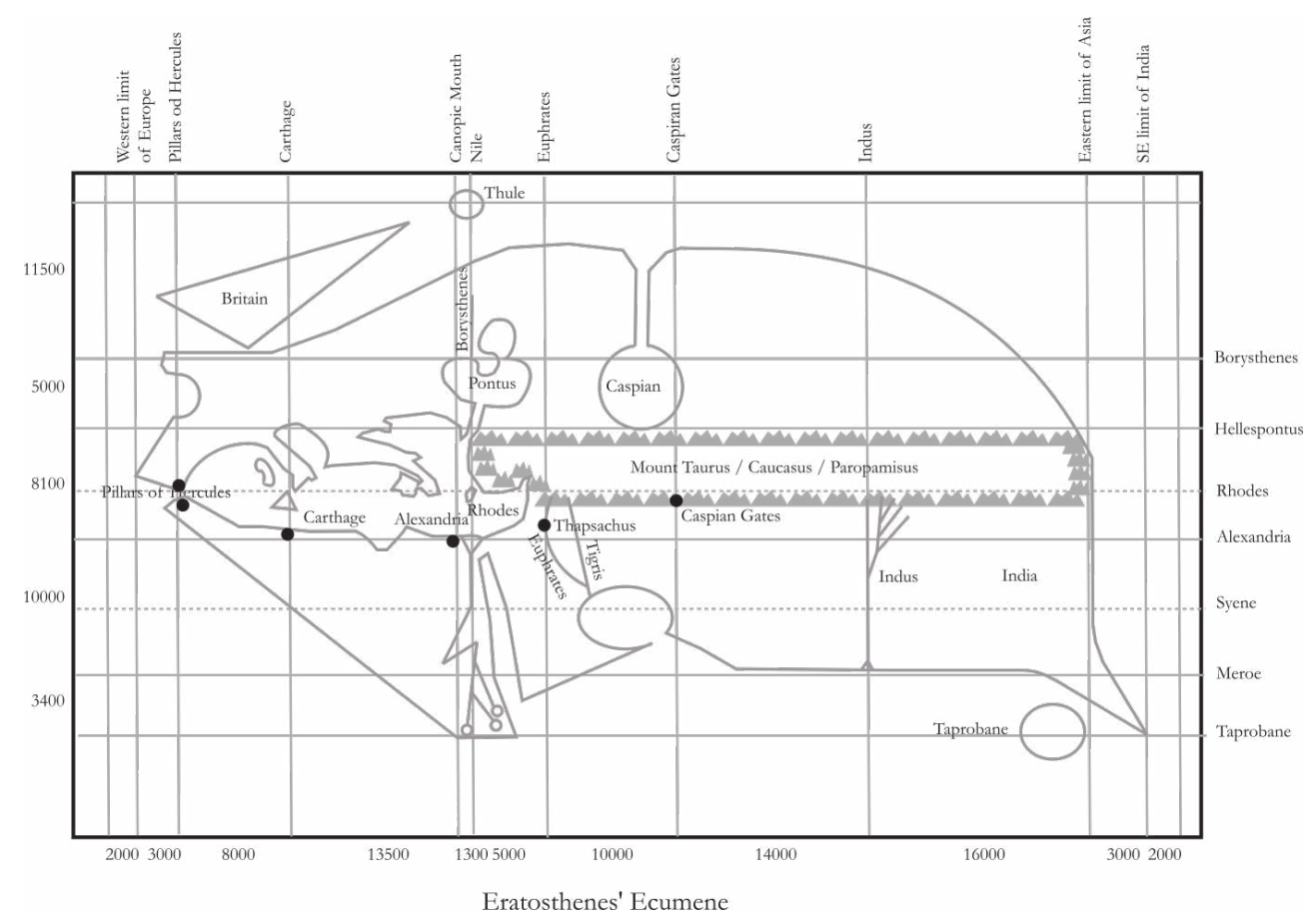

Strabo's world, more than two hundred years later, had evolved, as the cape of spices became a more salient feature. Even if Strabo does not explicitly mention cape Syagros, a more salient landmark appears on the map. At the same time, Sri Lanka becomes elongated and is considered as larger than the British Isles (Fig. 8).

Figure 8. Strabo's world

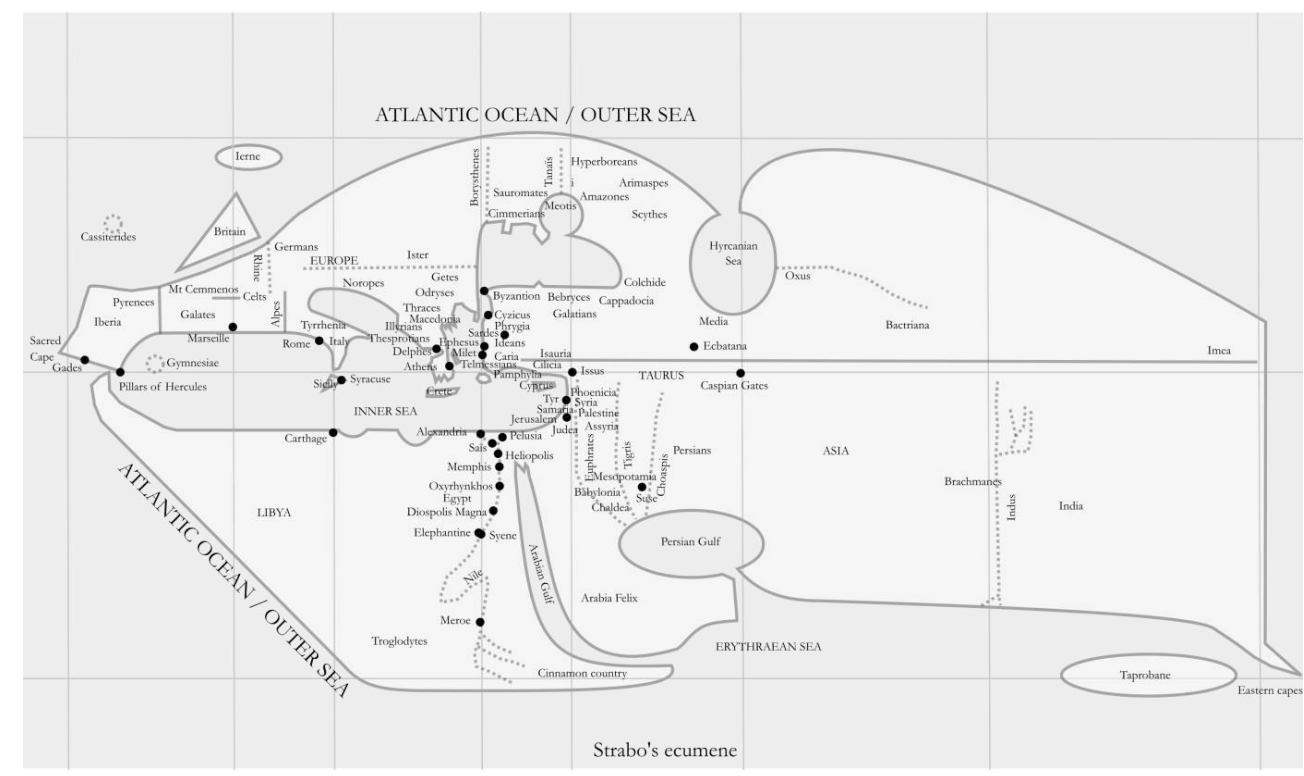

From Eratosthenes to Ptolemy, there are constant features, as Taprobane seems to be placed on the same latitude as cape Gardafui, while the different mouths of the Indus are connected to the Arabian Peninsula.

Ptolemy's representation of the Indian Ocean seems to be underpinned by a longlasting geographic tradition highly influenced by the growing experience of navigation 
and travel which led historians to draw comparisons between the different areas they knew. For instance, around 130 CE Arrian writes in his Indika (Book 8, chapter 6):

The plains of India also receive rain in summer, and much part of them becomes swamp; in fact Alexander's army retired from the river Acesines in midsummer, when the river had overflowed on to the plains; from these, therefore, one can gauge the flooding of the Nile, since probably the mountains of Ethiopia receive rain in summer, and from them the Nile is swollen and overflows its banks on to the land of Egypt. The Nile therefore also runs turbid this time of the year, as it probably would not be from melting snow; nor yet if its stream was dammed up by the seasonal winds which blow during the summer; and besides, the mountains of Ethiopia are probably not snow-covered, on account of the heat. But that they receive rain as India does is not outside the bounds of probability; since in other respects India is not unlike Ethiopia, and the Indian rivers have crocodiles like the Ethiopian and Egyptian Nile; and some of the Indian rivers have fish and other large water animals like those of the Nile, save the river-horse: though Onesicritus states that they do have the river-horse also. The appearance of the inhabitants, too, is not so far different in India and Ethiopia; the southern Indians resemble the Ethiopians a good deal, and, are black of countenance, and their hair black also, only they are not as snub-nosed or so woolly-haired as the Ethiopians; but the northern Indians are most like the Egyptians in appearance. (Arrian 1929)

According to Arrian, Egypt and India share many common features: similar weather conditions, animals, and even people. It seems therefore relevant that both Egypt and India should be placed on similar latitudes.

This tradition was enhanced by sailors' experiences. India looked like a diamond with angles stretching east and west rather than north and south. This representation was accepted up to Marcus Agrippa, whose works were reused by Pliny the Elder who knew the maritime route that connected Bal-al-Mandab and the southern part of India within 40 days (vol. II, book 6, chap. 26):

Passengers generally set sail at midsummer, before the rising of the Dog-star, or else immediately after, and in about thirty days arrive at Ocelis in Arabia, or else at Cane, in the region which bears frankincense. There is also a third port of Arabia, Muza by name; it is not, however, used by persons on their passage to India, as only those touch at it who deal in incense and the perfumes of Arabia. More in the interior there is a city; the residence of the king there is called Sapphar, and there is another city known by the name of Save. To those who are bound for India, Ocelis is the best place for embarcation. If the wind, called Hippalus, happens to be blowing, it is possible to arrive in forty days at the nearest mart of India, Muziris by name. This, however, is not a very desirable place for disembarcation, on account of the pirates who frequent its vicinity, where they occupy a place called Nitrias; nor, in fact, is it very rich in articles of merchandize. Besides, the road-stead for shipping is a considerable distance from the shore, and the cargoes have to be conveyed in boats, either for loading or discharging. At the moment that I am writing these pages, the name of the king of this place is Cælobothras. Another port, and a much more convenient one, is that which lies in the territory of the people called Neacyndi, Barace by name. Here King Pandion used to reign, dwelling at a considerable distance from the mart in the interior, in a city known as Modiera. (Pliny 1855: 64-5)

Under the reign of the emperor Claudius in the middle of the $1^{\text {st }}$ century AD (Casson 1989), the route to Sri Lanka was definitely open for sailors. Pliny testifies that several sources attest to an important development of maritime knowledge around the middle of the $1^{\text {st }}$ century AD. 

changes occurred at the turn of the $2^{\text {nd }}$ and the $1^{\text {st }}$ century BC, however, when Greek sailors came to realize Monsoon winds could probably help them sail directly from Africa to India without navigating along the coast from Bab al-Mandab to the province of Gujarat (Marcotte 2016). Indian and Arab sailors had probably sailed this route before them, as Pliny the Elder (vol. II, book 6, chap. 26:62-3) writes that the Monsoon wind was called Hippalus by the natives. There is archaeological evidence of Greek trading in the south of India since the $2^{\text {nd }}$ century BC as many Greek amphorae have been found in the South-East around Arikamedu (Mathew 2017; Will 1996, 2004). It should also be mentioned that after the fall of the Mauryan Empire, a Greek Seleucid satrap called Diodotus settled a kingdom in 240 BC in Bactriane and Sogdiana. Later on, these sailors discovered the route from this strait to the harbor of Mouziris on the Southern coast of India. From this location, they could also sail to Sri Lanka. and the Red Sea. These routes threatened Arab caravan routes along this sea. The harbors of Berenice and Myos Hormos developed during the Ptolemies, but harbors were also founded on the Arabian side, such as Ampelone, north of modern Jeddah. At the very beginning of the $3^{\text {rd }}$ century BC, Ptolemy II decided to dig the canal Darius had drawn between the Nile and the Red Sea 200 years earlier. From this date, the canal made it possible for sailors to not unload their ships on their way from the Mediterranean to the Red Sea, even if this canal followed a different course than the modern Suez Canal (Schörner 2000).

Cities quickly developed in our era, while both maritime and land routes remained nearly identical, despite a growing number of coastal cities fostered by coastal trade and maritime expansion. Egyptian trade decreased during the $1^{\text {st }}$ century and the Roman conquest in $30 \mathrm{BC}$ served as a new starting point. Trade with the Middle East and the Far East became more important, as the Indian Ocean became the center of gravity of globalization.

\section{Conclusion}

The Ancients' representation of the Indian Ocean was based both on a vivid literary tradition and the growing knowledge about the environment attributable to the sailing experience of merchants who gradually helped map the world. The main geographers' concern was not to draw precise scientific maps, but to make understandable and measurable what was visible. Their representations of maritime spaces is mostly consistent with Pietro Janni's "odological space" (Janni 1984), which contrasts sharply with cartographical representations of space because of the introduction of cultural and cognitive features that influenced the perception of geographic entities. At the very beginning of the Christian era, the basic schemes, routes and nodes of trade had already been laid out. The typology of goods that would be sold between east and west were largely the same as in modern times: luxury goods, silk, cotton, spices or pepper, carried over long distances for trade. The world was ready for a new globalization with new generations of sailors and new experiences of navigation that would contribute to shape new representations of the Indian Ocean.

Angles, 9 | 2019 


\section{BIBLIOGRAPHY}

Alpers, Edward A. The Indian Ocean in World History. Oxford: Oxford UP, 2014.

Anson, Edward M. Alexander's Heirs. The Age of the Successors. Chichester: Wiley Blackwell, 2014.

Arnaud, Pascal. Les Routes de la navigation antique. Itinéraires en Méditerranée. Paris: Éditions errance, 2005.

Arrian. Anabasis Alexandri. Indica. Transl. E. Liff Robson. London: Heinemann, Loeb Classical Library, 1929.

Beaujard, Philippe. "Un seul système-monde avant le 16e siècle ? L'océan Indien au cœur de l'intégration de l'hémisphère afro-eurasien.” In P. Beaujard, L. Berger et P. Norel. Histoire globale, mondialisations et capitalisme. Paris: La Découverte, 2009: 82-148.

Beaujard, Philippe. Les Mondes de l'océan Indien. Paris: Armand Colin, 2012.

Casson, Lionel (transl.). The Periplus Maris Eythraei. Princeton: Princeton UP, 1989.

Gibson, J.J. The Ecological Approach to Visual Perception. Boston: Houghton Miffin, 1979.

Hammond, N.G.L. Three Historians of Alexander the Great. New York: Cambridge UP, 2007.

Janni, Pietro. La mappa e il periplo : cartografia antica e spazio odologico. Rome: Breithschneider, 1984.

Khalil, Emad K. H. "Egypt and the Roman Maritime Trade: a focus on Alexandria." PhD Dissertation, University of Southampton, 2005.

Marcotte, Didier. "The Indian Ocean from Agatharchides of Cnidus to the Periplus Maris Erythraei." In Serena Bianchetti et al. (ed.). Brill's companion to Ancient Geography: the inhabited world in Greek and Roman tradition. Leiden: Brill, 2006: 163-183.

Marcotte, Didier (ed.). Néarque, d'Arrien à Alexandre, d'Arrien à William Vincent : le périple de Néarque et sa postérité. Estratto da Geographia Antiqua, xxii. Firenze: Leo S. Olschki Editore, 2013.

Marcotte, Didier. "L'océan Indien des Grecs, entre tradition savante et actualité maritime." In Emmanuelle Vagnon and Eric Vallet (eds.). La Fabrique de l'océan Indien. Cartes d'Orient et d'Occident (Antiquité-XVIe siècle). Paris: Publications de la Sorbonne, 2016: 7-14.

Méla, Charles \& Frédéric Möri. Alexandrie la Divine. 2 Vol. Neuchâtel: La Baconnière, 2014.

Müller, Karl. Geographi Graeci Minores. Vol. I. Paris: Firmin Didot, 1855.

Müller, Karl. Geographi Graeci Minores. Vol. II. Paris: Firmin Didot, 1861.

Pliny. The Natural History of Pliny. John Bostock and H.T. Riley (trans.). Vol. II. London, 1855.

Mathew K.S. (ed.). Imperial Rome, Indian Ocean Regions and Muziris, New Perspectives on Maritime Trade. New York: Routledge, 2017.

Ray, Himanshu Prabha. “A resurvey of Roman Contacts with the East.” Topoi 3.2 1993: 479-491. DOI: $10.3406 /$ topoi.1993.1481

Reade, Julian. The Indian Ocean in Antiquity. London: Routledge, 2009.

Reclus, Elisée. L'Homme et la terre. Vol. III. Paris: Librairie Universelle, 1905.

Salles, Jean-François. "The Periplus of the Erythraean Sea and the Arab-Persian Gulf.” Topoi 3.2 (1993): 493-523. DOI: $10.3406 /$ topoi.1993.1482 
Schörner, Hadwiga. "Künstliche Schiffahrtskanäle in der Antike. Der sogenannte antike SuezKanal.” Skyllis 3-1 (2000): 28-43.

Strabo. Geography. Books 1-2. Trans. Horace Leonard Jones. London: Harvard UP, 2005.

Will, Elizabeth Lyding. "Mediterranean shipping amphoras from the 1941-50; Excavations (at Arikamedu)." In V. Begley (ed.). The Ancient Port of Arikamedu: New Excavations and Researches, 1989-1992. Vol. I. Paris: Centre d'Histoire et d'Archéologie, École Française d'Extrême-Orient, 1996: 325-403.

\section{ABSTRACTS}

Navigations in the Indian Ocean, well attested in the ancient periplographical and geographical literature, pose a series of questions to the historian. These investigations are more often than not fragmentary and provide information only on some of the desired data. Nor can they attest the existence of cartographic representations. However, whether they are Greek or Latin, many navigators had experienced what is was to sail in the Indian Ocean at that time, offering a constantly evolving representation of this area.

Les navigations en océan Indien, bien attestées dans la littérature périplographique et géographique ancienne, posent une série de questions à l'historien. Plus encore que d'autres, elles sont parcellaires et ne renseignent que sur une partie des données souhaitées. Elles ne permettent pas non plus d'attester l'existence de représentations cartographiques. Pourtant, qu'ils soient grecs ou latins, de nombreux navigateurs ont fait l'expérience de la navigation en océan Indien au fil de l'Antiquité, proposant une représentation en constante évolution.

\section{INDEX}

Keywords: navigation, Antiquity, geography, voyage, Indian Ocean, sea

Mots-clés: navigation, antiquité, géographie, périple, Océan Indien, mer

\section{AUTHOR}

\section{JEAN-MARIE KOWALSKI}

Associate Professor (Ancient History) at the University of Paris-Sorbonne. Jean-Marie Kowalski wrote a doctoral thesis entitled "Thalassographeïn, Mesure, Representation et Description of Maritime Spaces in Ancient Greece," under the joint guidance of Prof. Arnaud Zucker (University of Nice) and Prof. Christophe Claramunt (Naval School). Since 2007, he has been head of the Department of Humanities at the French Naval Academy. His fields of research are navigation, naval operations and military ethics. He is attached to the Laboratoire d'histoire et d'archéologie maritimes - FED 4124 (Sorbonne Université). The book entitled Navigation et géographie dans l'antiquité gréco-romaine (Éditions A\&J Picard, 2012) and the article "Du héros épique à l'ennemi public : représentations antiques de la figure du pirate" published in the volume La piraterie au fil de l'histoire : un défi pour l'Etat (Paris, PUPS, 2014) and Images des Américains dans la Grande Guerre (Presses universitaires de Rennes, 2017) feature among the numerous publications he has authored. Contact: jean-marie.kowalski[at]ecole-navale.fr 